\title{
Türkiye Sağlık Politikalarının Katastrofik Harcama Yapan Hanelere Etkisi
}

\section{Güvenç KOÇKAYA ${ }^{1}$}

\section{ARTICLE INFO}

Article History:

Date Submitted: 03.06.2017

Date Accepted: 01.08.2017

JEL Classification:
I14
I31
I32

Keywords:

Catastropic

Health Expenditure

\begin{abstract}
Yrd. Doç. Dr. Berna Tuncay ve Yrd. Doç. Dr. Aysun Aygün'le ortak çalışmaları olan Türkiye'de katastrofik sağlık harcamalarında yaşanan yükseliş nedeninin araştırılması başlıklı çalışmada 2011-2012'den sonra katastrofik sağlık harcaması yapan hanehalkı sayısında artış olduğu ve bunun nedenlerinin açığa çıartılmasının önemi vurgulamıştır. 2003 yılından itibaren çok farklı sağlık politikalarının uygulandığını belirten sayın Koçkaya, özellikle 2010 yılında sağlık sigortacılığı kapsamının arttırılması, 2012 yılından beri ilaç harcamalarında devletin uyguladığı yeni önlemler, 2012-13'den itibaren de tıbbi cihaz harcamalarına yönelik geri ödeme politikaları uygulanmaya başlandığını belirten Koçkaya, 2014 yılında da yurt dışı ilaç süreçlerine yeni politikalar uygulanmaya başladığını belirtmiştir. Bunların olası sebebinin 2003'de sağlıkta dönüşüm ile daha önceki yılların beklemiş talebinin sağlık bütçelerinin beklentilerin üzerinde arttırması olduğunu belirten Koçkaya, devletin söz konusu harcamaları kontrol etmek amacıyla önlemler almasının doğal olduğunu dillendirmiştir.
\end{abstract}

\footnotetext{
${ }^{1}$ Sağlık Ekonomisi Politikası Derneği Başkanı, guvenckockaya@kockaya.net
} 
Yrd. Doç. Dr. Berna Tuncay ve Yrd. Doç. Dr. Aysun Aygün'le ortak çalışmaları olan Türkiye'de katastrofik sağlı harcamalarında yaşanan yükseliş nedeninin araştırılması başlıklı çalışmada 2011-2012'den sonra katastrofik sağlık harcaması yapan hanehalkı sayısında artış olduğu ve bunun nedenlerinin açığa çıkartılmasının önemi vurgulamıştır. 2003 yılından itibaren çok farklı sağlık politikalarının uygulandığını belirten Sayın Koçkaya, özellikle 2010 yılında sağlık sigortacılığı kapsamının arttırılması, 2012 yılından beri ilaç harcamalarında devletin uyguladığı yeni önlemler, 2012-13'den itibaren de tıbbi cihaz harcamalarına yönelik geri ödeme politikaları uygulanmaya başlandığını belirten Koçkaya, 2014 yılında da yurt dışı ilaç süreçlerine yeni politikalar uygulanmaya başladığını belirtmiştir. Bunların olası sebebinin 2003'de sağlıkta dönüşüm ile daha önceki yılların beklemiş talebinin sağlık bütçelerinin beklentilerin üzerinde arttırması olduğunu belirten Koçkaya, devletin söz konusu harcamaları kontrol etmek amacıyla önlemler almasının doğal olduğunu dillendirmiştir.

Sağlıkta dönüşümün ikinci fazına geçildiğini ifade eden Koçkaya, sağl1kta erişimin birinci faz ile bir sorun olmaktan çıktığını artık kalitenin önemli olduğunu belirtmiştir. Bu yeni durumun da doğal olarak sağlık harcamalarını yine arttıracağını belirtmiş, kamu özel ortaklığıyla yapılan şehir hastanelerini bu duruma örnek olarak sunmuştur. Şehir hastaneleri son derece önemli olmakla birlikte sağlık harcamalarını arttıracağının da aşikar olduğunu dillendiren Koçkaya, söz konusu hastanelere ilişkin olarak \%70'lerde bir yatak doluluğu garantisi verilmesinin ve hastanelerin dolmaması durumunda aradaki farkın devlet tarafindan ödenmesi gerekliliğinin harcamaları arttırabileceğini belirtmiştir. Hastanelerin orta ve uzun dönemde belirtilen doluluk oranlarına kavuşacağını ve üzerine çıkacağını da belirten Koçkaya, tüm bu politikaların devletin yaptığı sağlık harcamalarını arttırabileceğini bu durumda devletin yükünü hafifletmek adına sağlık harcamalarından bir kısmını vatandaşa cepten harcama ile veya tamamlayıcı sağlı sigortası aracılığı ile devretmesinin makul karşılanması gerekliliğinin altını çizmiştir.

Koçkaya yaptıkları çalışmanın TUIK raporlarına göre 2011 yılından itibaren yükselişe geçen katastrofik sağlık harcamasının artış nedenlerini açığa çıkartmak olduğunu belirtmiştir. Çalışmada verilen farklı hasta gruplarına göre ve ek olarak daha önce yapılmamış olan, yapılan harcama kalemlerinin oranlarına bakmaya çalıştıklarını ifade etmiştir. Hane halklarının harcamalarını hangi tıbbi alanlara yoğunlaştı̆̆ına dair yani ilaç, tıbbi malzeme, hekim, hastane, 
tıbbi hizmetler gibi hangi alanlarda ne kadar harcama yapıldığını açığa çıkartmaya çalıştıklarını belirtmiştir.

Çalışma sonuçlarına göre katastrofik sağlık harcamaları yapanların oranı 2007 yılında $\% 0,81$ 'den 2012 y1lında $\% 0.25$ 'e düşmüş; fakat daha sonra tekrar artarak 2014 yılında \%0.40'a yükselmiştir.

Son dönemdeki politikaların etkilerine bakıldığında ilaç harcamalarının azaldığını belirten Koçkaya, söz konusu politikalar neticesinde hem devlet harcamalarının azaldığını hem de vatandaşın cepten harcama yapmasının azaldığını belirtmiştir. 2007-2014 arasında eczacılık ile ilgili ürünler, tıbbi hizmetler, hastane hizmetleri, dişçilik, laboratuvar hizmetlerine pozitif harcama yapan kişilerin ortalama harcama değerleri azalmış, tıbbi ürünler, tıbbi yardımcı hizmetler ve diğer hizmetlere pozitif harcama yapan kişilerin ortalama harcama değerlerinde ise artışlar olduğunu vurgulamıştır. Politikaların ilaç sektörü üzerindeki etkisi her ne kadar sektör tarafından eleştirilmiş olsa da olumlu sonuçlar verdiğini sağlık harcaması yapılan hanelerde ilaca yapılan harcamanın azalmasından hareketle altını çizen Koçkaya, ancak diğer tıbbi ürünlere yönelik harcamalarda büyük artışlar olduğunu da belirtmiştir.

Koçkaya, doktora yapılan ödemelerde bir azalma olduğunu belirtmiş ve bunun tam gün yasası ile açıklanmasının mümkün olduğunu ifade etmiştir. Sağlık Bakanlığının her ilçeye her hastaneye bir diş hekimi projesinin de dişçilik hizmetlerine yönelik harcamaların azalmasına sebep olabileceğini belirten Koçkaya, Laboratuvar ve röntgen merkezleri harcama kalemlerindeki azalmanın da önemli olduğunu altını çizmiştir. Hastane hizmetlerinde de oransal olarak önemli bir azalma olduğunu artışların ise tedavide kullanılan alet ve ekipmanlar ve tıbbi yardımcı hizmetler olduğunu belirtmiştir.

Sayın Koçkaya katastrofik sağlık harcaması yapan hanehalklarında kategorilerine göre sağlık harcamalarının toplam harcamalarına oranındaki değişımi aşağıdaki tablo ile sunmuştur. 
Tablo 1 - 2007-14 Kategorilere Göre Harcama Oranı Değişimleri

\begin{tabular}{|c|c|c|c|c|c|}
\hline & \multicolumn{2}{|c|}{$\mathbf{2 0 0 7}$} & \multicolumn{2}{|c|}{$\mathbf{2 0 1 4}$} & $\mathbf{2 0 0 7 - 2 0 1 4}$ \\
\hline $\begin{array}{c}\text { Toplam sağlık } \\
\text { harcamalarına oranı }\end{array}$ & Harcama oranı & $\begin{array}{c}\text { Harcama } \\
\text { Yapmayan oranı }\end{array}$ & Harcama oranı & $\begin{array}{c}\text { Harcama } \\
\text { Yapmayan oranı }\end{array}$ & $\begin{array}{c}\text { Harcama oranı } \\
\text { değişim }\end{array}$ \\
\hline $\begin{array}{c}\text { Eczacilıkla ilgili } \\
\text { ürünler }\end{array}$ & $21.9(33.29)$ & $0.29(0.457)$ & $7.732(22.83)$ & $0.425(0.501)$ & $-\% 64$ \\
\hline $\begin{array}{c}\text { Tedavide kullanılan } \\
\text { alet ve ekipmanlar }\end{array}$ & $5.369(19.74)$ & $0.913(0.284)$ & $9.616(26.56)$ & $0.850(0.362)$ & $+\% 79$ \\
\hline $\begin{array}{c}\text { Tıbbi hizmetler } \\
\text { (doktor) }\end{array}$ & $21.64(30.29)$ & $0.478(0.503)$ & $9.130(16.64)$ & $0.500(0.506)$ & $-\% 57$ \\
\hline Dișçilik hizmetleri & $18.84(38.0)$ & $0.783(0.415)$ & $17.62(38.02)$ & $0.700(0.464)$ & $-\% 6$ \\
\hline $\begin{array}{c}\text { Laboratuvarlar ve } \\
\text { röntgen merkezleri }\end{array}$ & $6.198(16.36)$ & $0.812(0.394)$ & $5.862(12.49)$ & $0.775(0.423)$ & $-\% 5$ \\
\hline $\begin{array}{c}\text { Tibbi yardımcı } \\
\text { hizmetler }\end{array}$ & $3.323(16.04)$ & $0.928(0.261)$ & $9.761(29.67)$ & $0.900(0.304)$ & $+\% 193$ \\
\hline Hastane hizmetleri & $18.53(36.57)$ & $0.768(0.425)$ & $35.83(43.88)$ & $0.475(0.506)$ & $+\% 93$ \\
\hline
\end{tabular}

Koçkaya yukarıdaki tablodan hareketle fakirleştirici harcama yapan bireylerin tedavide kullanılan alet ve ekipmanlar, tıbbi yardımcı hizmetler ve hastane hizmetlerinde büyük artış olduğunu belirtmiştir. Genel popülasyonda hastane hizmetlerinde bir düşüş varken katastrofik hane halklarında ise bir artış olmasının nedenini bulmanın önemli olduğunu belirten Koçkaya, bunun nedeni olarak spesifik önemli ameliyatları yapabilen hekimlerin özel hastanelere geçmeleri ile spesifik hastalıklarda harcamaların artmasına neden olmuş olabileceğini ifade etmiştir. Bir diğer nedenin ise Sosyal Güvenlik Kurumu anlaşmalı hastanelerin fark oranlarını \%200'e çıkartmış olması olabileceğini belirtmiştir. SGK'nın bugün yüz lira ödediği bir hizmete özel hastanelerin maksimum 200 lira alması gerekirken, otelcilik hizmeti altında bu farkın çok daha üstünün hastaların önüne koyabildiğini belirten Koçkaya bu durumun söz konusu harcamaları arttıran bir diğer faktör olabileceğinin altını çizmiştir. Tıbbi malzemenin geri ödemesi sisteminde bir takım sorunlar olduğunu dillendiren Koçkaya, ilaçta kurumsallaşmış bir süreç olduğunu buna karşın tıbbi malzemede böylesi bir durumun olmamasının harcamaları arttıran neden olabileceğini belirtmiştir. Özellikle spesifik hastalıkların cerrahisinde bazı tıbbi malzemeler için Sosyal Güvenlik Kurumu`nun belirlediği rakamların, söz konusu ürünlerin alınması için yeterli olmadığını ve hastaların özel hastaneler ve üniversite hastanelerinin bir kısmında tedavileri için söz konusu ürünleri, kendileri temin etmek zorunda kaldıklarını belirtmiştir. Dolayısıyla spesifik hastalıklardan kaynaklı olarak tıbbi cihazlara yapılan harcamalarda hane halkı harcamaları içerisinde artış olabileceğini belirtmiştir.

Koçkaya yukarıdaki tabloki verilerden hareketle bu yorumların yapıldığını ancak gerçek sebeplere ilişkin olarak daha detaylı araştırmalara gerek olduğunu da özellikle belirtmiş ve 
ilaçta yapılanlara benzer politikalar ile harcamaların yüksek olduğu alanlarda harcamaların azalmasının gerçekleşmesi temennisini paylaşmıştır.

Zengin ve fakir açısından harcama durumları değerlendirildiğinde fakirlerin harcama yapmayarak sağlık hizmetlerinden faydalanmamayı tercih ettiklerini yani seçim yanlılı̆̆ sorunu olduğunu belirten Koçkaya, 65 yaş üstü ve beş yaşından küçük ya da engelli olan hanelerde, katastrofik harcamanın daha fazla olduğunu da değerlendirmelerine eklemiştir. Beklenenin dışında erkeklerin daha fazla katastrofik harcama yaptıklarını da belirtmiştir.

Türkiye, sağlıkta dönüşümle reformu ile gelişmiş sosyal sistemlerde olan binde birlik katastrofik harcama yapan hane oranına ulaşmak üzereyken tekerleğin ters dönmeye başladığ ve bu orandan uzaklaşmaya başladığını hatırlatmıştır. Bunun nedenlerinin çok boyutlu olduğunun altını çizen Koçkaya, bu nedenlerin açığa çıkartılması için çok sayıda çalışma yapılmasının gerekliliğini vurgulamıştır. Bu yapılan çalışmalar ışığında sağlık politikalarının yeniden gözden geçirilmesi ve güncellenmesinin de öneminin altını çizmiştir.

Çalışmanın önemli bir katkısının da Sağlık politikalarının ve harcamalarının gözden geçirilmesinde aslında azalmakta olan harcama kalemlerinde bir miktar düzenlemeler ile devletin bütçesine olumlu katkı sağlanması ve katkının diğer alanlarda kullanılmasının planlanabileceğini belirten Koçkaya, örnek olarak cepten yapılan ilaç harcamalarında yaşanan azalma sayesinde uzun süredir bekletilen OTC İlaç tasarısının değerlendirilebileceğini, bazı ilaçların eczanelerde satılmasına devam edilmesine rağmen Sosyal Güvenlik Kurumu geri ödemesinden çıkarılabileceğini belirtti. İlaçların eczanelerde satılmasının halk sağlığı için önemli olduğunu ancak her ilacın devlet tarafından ödenmesinin de zorunlu olmadığını vurguladı. Bu durumun belki cepten yapılan ilaç harcamalarında bir miktar artışa neden olabileceğini hatta reçete kaymasına da sebep olabileceğini ancak buradan yapılabilecek yaklaşık 1-2 milyar TL lik tasarruf ile fakirleştirici sağlık harcamasını arttırıcı etkisi olduğu muhtemel olan tıbbi malzeme, hastane hizmetleri gibi alanlarda alınacak politika kararlarının finansmanında kullanılabileceğini vurguladı.

Sonuç olarak, sağlık politikasındaki değişimler sonucunda katastrofik sağlık harcaması yapan hanelerin eczacılık, hekim ve diş hekimliğine yönelik harcamaların azaldığı ancak tıbbi 
ürünler, tedavide kullanılan alet ve ekipmanlar, diğer tıbbi ürünler, tıbbi yardımcı hizmetler ve diğer hizmetlere yapılan harcamaların gerek oran gerekse değer olarak artış gösterdiği ve bunun katatstrofik harcama yapan hane sayısını arttırmış olabileceği üzerinde duran Koçkaya, bu durumun ileri araştırmalar ile açığa çıkartılması gerektiğinin altını çizmiştir. 